Case Report

\title{
Skin Manifestations Associated With Mantle Cell Lymphoma: a Case Report
}

Avinash Kumar Singh ${ }^{1}$, Gaurav Dixit ${ }^{1}$, Sanjeev Sharma ${ }^{1}$, Suman Kumar ${ }^{1}$, Rajni Yadav $^{2}$, Narendra Agrawal $^{1}$, Pravas Mishra $^{1}$, Tulika Seth ${ }^{1}$, C.Sarkar ${ }^{2}$, M.Mahapatra ${ }^{1}$ and Renu Saxena ${ }^{1}$

${ }^{1}$ Department of Hematology, All India Institute of Medical Sciences, New Delhi

${ }^{2}$ Department of Pathology, All India Institute of Medical Sciences, New Delhi

Correspondence to: Avinash Kumar Singh, Department of Hematology, All India Institute of Medical Science, New Delhi, India. E-mail: avinash.pmch@gmail.com

Competing interests: The authors have declared that no competing interests exist.

Published: February, 252013

Received: December 18, 2012

Accepted: February 20, 2013

Citation: Mediterr J Hematol Infect Dis 2013, 5(1): e2013020, DOI: 10.4084/MJHID.2013.020

This article is available from: http://www.mjhid.org/article/view/11310

This is an Open Access article distributed under the terms of the Creative Commons Attribution License (http://creativecommons.org/licenses/by/2.0), which permits unrestricted use, distribution, and reproduction in any medium, provided the original work is properly cited.

Abstract. Mantle cell lymphoma (MCL) is a distinct non-Hodgkin's lymphoma type that commonly affects extra nodal sites. The most often affected sites are bone marrow, gastrointestinal tract and Waldeyer's ring, being the skin rarely involved. We report a case of 56 year-old man with MCL, exhibiting multiple large maculopapular skin rashes and skin ulcers. Histopathological examination had not shown direct infiltration by any atypical cells. He had significant improvement of skin lesions with combination chemotherapy and debridement. Awareness of skin manifestations of MCL is crucial for dermatologists and haematologists to establish the early diagnosis and timely administration of appropriate treatment.

Case Report. A 56 years old indo-aryan black gentleman, farmer by occupation, occasional smoker and alcoholic for more than 20 years, presented to Haematology OPD with complains of weakness and easy fatigability for one month, he also had glandular swellings involving the neck, axilla and inguinal region. He noticed erythematous maculopapular rashes over both upper limbs, 2 days back. There was no history of fever, cough, bleeding, skeletal pain or jaundice. There was no involvement of the oral mucosa by the skin lesions. The past and family history was not significant. On examination, he had generalised lymphadenopathy and massive hepatosplenomegaly. The skin rashes (Figure 1) were maculopapular erythematous, size varying from $4 \times 5 \mathrm{~cm}$ to $10 \times 8 \mathrm{~cm}$ without any initial itching, pain or secretion. Over 4 to 5 days, the rashes developed blackish discolouration, followed by bullae formation that eventually ruptured. The blood exam revealed anemia, thrombocytopenia and leucocytosis $\left(\mathrm{WBC}=18000 / \mathrm{mm}^{3}\right)$ with presence of atypical lymphoid cells on peripheral smear. The bone marrow examination showed $45 \%$ immature

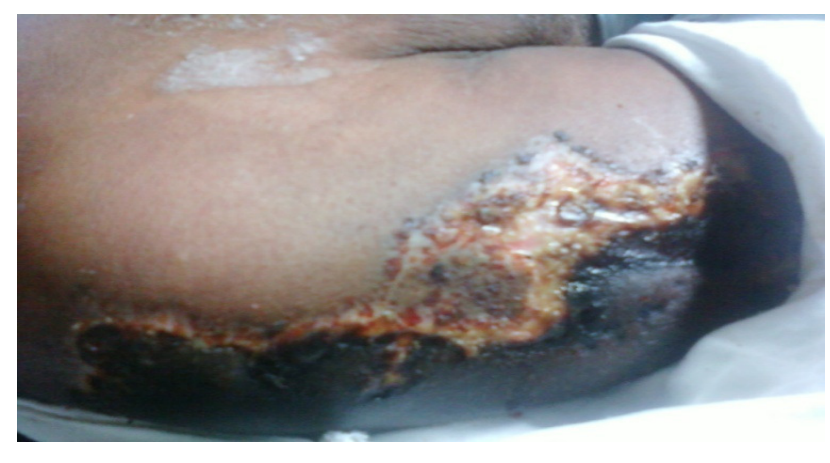


Figure 1. Skin lesion with central necrosis over right arm lymphoid cells, negative for MPO, SB, AP, NSE \& PAS on cytochemistry. The bone marrow biopsy showed infiltration by atypical lymphoid cells. Immunophenotyping by flow cytometry of bone marrow showed positivity for co-expression of CD19/5, CD19, FMC7, Kappa clonality, CD25, HLADR, CD22, CD20, CD79b, SIgM and negative for co-expression of CD23/5, CD10, CD23, CD11C, CD103, CD2, CD3, CD34, SIgG, TdT. The axillary lymph node biopsy was suggestive of blastoid variant of mantle cell lymphoma, which showed immunopositivity for CD 20, CD43, Cyclin D1, BCL2, BCL-6 and immunonegative for CD5, CD3, CD10, CD23. The skin biopsy from the left arm maculopapular lesion (including both healthy and affected area) showed congested vessels along with extravasations of $\mathrm{RBC}$ in the dermis without any atypical lymphoid cells (Figure 2a and 2b). He received R-CHOP chemotherapy and has undergone debridement (Figure 3) for the skin lesions. Gradually, after 5 cycles of chemotherapy, he has attained complete remission of skin lesions along with disappearance of lymphadenopathy, organomegaly and normalisation of the hemogram.

Discussion. Mantle cell lymphoma (MCL) is a malignant tumor derived from B cells in the mantle zone of lymphoid follicles characterized by specific

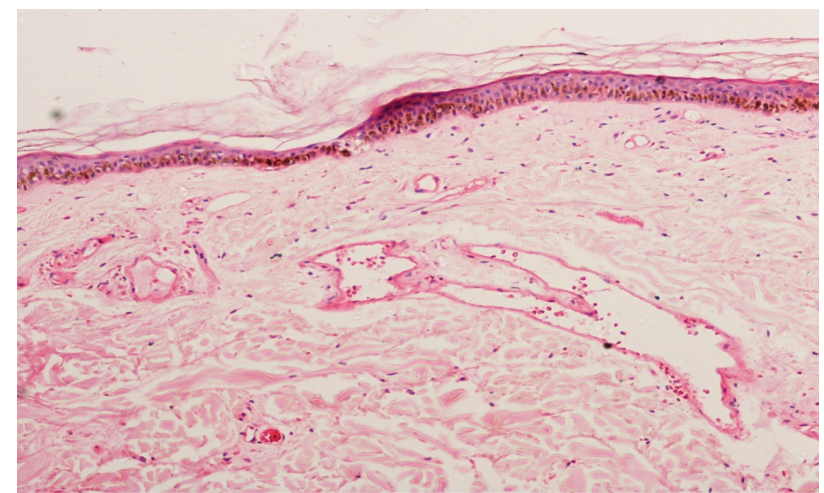

Figure 2a. Skin biopsy showing dilated and congested vessels

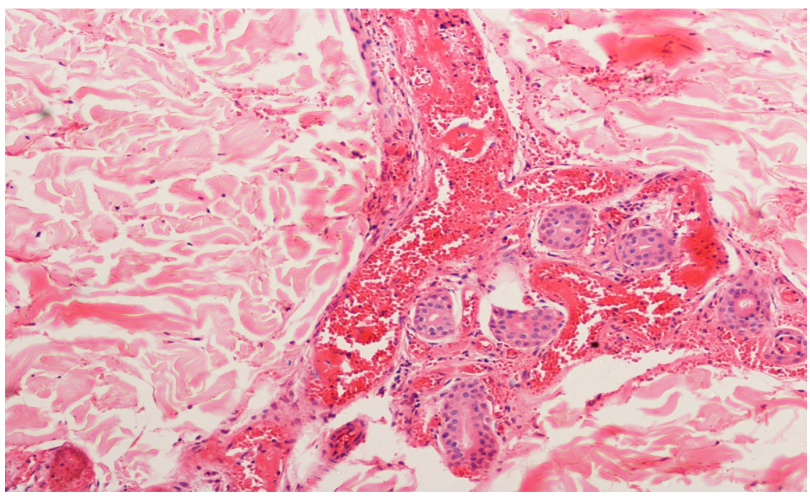

Figure 2b. Skin biopsy showing extravasation RBC in the dermis

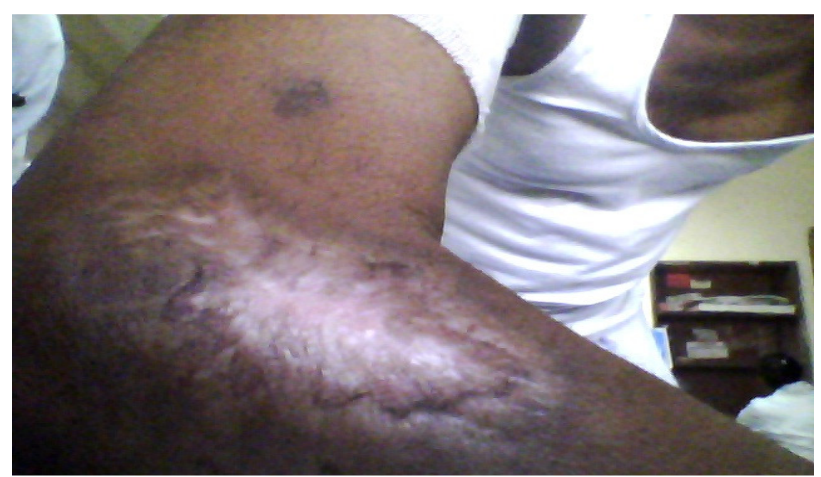

Figure 3. Skin lesion after 4 months

pathologic, immunophenotypic and molecular genetics features, and usually takes an aggressive clinical course, defined in the World Health Organization (WHO) classification. ${ }^{1-3}$ Histologically, it shows a diffuse or nodular monotonous proliferation of small lymphoid cells with scant cytoplasm and irregular nuclear contours in lymphnodes.

Immunophenotypically, the tumor cells are positive for B-cell markers CD79a, CD19, CD20 and CD22 as well as CD5, and are usually negative for CD10 and CD23." The majority of MCL have an associated cytogenetic abnormality $\mathrm{t}(11,14) \quad(\mathrm{q} 13 ; \mathrm{q} 32)$ translocation, which causes a juxtaposition of the CCND-1 gene on chromosome 11 with the immunoglobulin heavy chain gene on chromosome 14, resulting in an over expression of cyclin D1 protein, that leads to a positive signal for transition to the $S$ phase. ${ }^{7-9}$ Cyclin D1 over expression is considered to be an important diagnostic marker for MCL. ${ }^{10}$

MCL frequently involves extra nodal organs, particularly the bone marrow, gastrointestinal tract and Waldeyer's ring; thus it has been considered in the past as an extracutaneous lymphoma. However, MCL rarely affects the skin. In two large series of 121 and 59 cases of MCL, only 3 and 2 patients respectively had skin lesions, respectively. ${ }^{3,4}$ To the best of our knowledge, only 18 cases of mantle cell lymphoma with skin manifestation have been reported in English literature (Table 1). ${ }^{11,12}$ The commonly reported sites of skin involvement in MCL are trunk (60\%), face $(30 \%)$ followed by arm $(20 \%)$, thigh, leg \& scalp. ${ }^{11,12}$ Skin lesions manifested as nodular lesions in 6 patients $(34 \%)$, macular or maculopapular lesions, as in our case, in $6(34 \%)$, tumoral or infiltrated plaques in 4 $(21 \%)$, and subcutaneous nodules in $2(11 \%)^{11,12}$

In most of the reported cases of skin manifestations of MCL, skin lesion has shown infiltration by atypical lymphoid cells, while a reactive cutaneous eruption, simulating insect bites, has been only incidentally described in association with MCL. ${ }^{11,13-15}$ The skin involvement, even if rare, has been most frequently reported in the blastoid variant of $\mathrm{MCL}$ as in 
Table 1.

\begin{tabular}{|c|c|c|c|c|c|c|c|}
\hline No & Author & Age/Sex & Location & Clinical presentation & Extracutaneous Involvement & Stage & Prognosis \\
\hline 1 & Ellison & $66 \mathrm{M}$ & Temple & Macular skin lesions & $\begin{array}{l}\text { LN, liver, spleen, lung, pleural } \\
\text { cavity, CNS }\end{array}$ & IV & $\begin{array}{l}\text { D }(55 \mathrm{~d} \text {; after initial } \\
\text { hospitalization })\end{array}$ \\
\hline 2 & Geerts & $65 \mathrm{~F}$ & Forehead & Nodules & $\mathrm{LN}, \mathrm{BM}$ & IVA & $\mathrm{D}$ (1.5y; after diagnosis) \\
\hline 3 & Geerts & $77 \mathrm{~F}$ & Back, breast, arm & Tumoral plaques & Bronchus wall & IVA & \\
\hline 4 & Bertero & $51 \mathrm{M}$ & Breast & Subcutaneous nodule & LN, liver, spleen & IVA & A (17y; after onset) \\
\hline 5 & Bertero & $78 \mathrm{~F}$ & Breast, back & Nodules & None & IE & $\mathrm{D}$ (3y; after diagnosis) \\
\hline 6 & Bertero & $43 \mathrm{M}$ & Back, face, arm & Infiltrated plaques & LN, liver, spleen & IVA & A \\
\hline 7 & Bertero & $22 \mathrm{M}$ & Breast & Nodules & None & I E & A \\
\hline 8 & Marti & $61 \mathrm{~F}$ & Abdomen & Tumoral plaque & $\mathrm{LN}, \mathrm{BM}$, tonsils & IVA & $\mathrm{D}$ (15m; after diagnosis) \\
\hline 9 & Moody & $47 \mathrm{M}$ & Ear & Nodules & $\mathrm{LN}, \mathrm{BM}$ & IVA & A (3y; after onset) \\
\hline 10 & Dubus & $56 \mathrm{M}$ & Breast, back & Erythematous papules & LN, BM, PB & IVA & $\mathrm{D}$ (1y; after treatment) \\
\hline 11 & Dubus & $89 \mathrm{M}$ & $\begin{array}{l}\text { Breast, back, } \\
\text { abdomen }\end{array}$ & $\begin{array}{l}\text { Infiltrated purpuric } \\
\text { papules }\end{array}$ & LN, BM, PB & IVA & $\mathrm{D}(5 \mathrm{~d} ;$ after diagnosis $)$ \\
\hline 12 & Dubus & $72 \mathrm{M}$ & $\begin{array}{l}\text { Face, breast, arm, } \\
\text { axilla }\end{array}$ & Subcutaneous nodules & $\mathrm{LN}, \mathrm{BM}$ & IVA & A (1y; after treatment) \\
\hline 13 & Sen & $85 \mathrm{M}$ & Leg & Macular rash & LN. BM, buccal mucosa & IVB & D (20m; after onset) \\
\hline 14 & Sen & $76 \mathrm{M}$ & Thigh & Nodule & None & I E & A (30m; after onset) \\
\hline 15 & Sen & $56 \mathrm{M}$ & Chest & Nodules & BM, GI & IVA & A ( $21 \mathrm{~m}$; after onset) \\
\hline 16 & Sen & $57 \mathrm{M}$ & Legs & Maculopapular rash & LN, BM, PB & IVB & $\mathrm{D}(9 \mathrm{~m} ;$ after onset $)$ \\
\hline 17 & Sen & $61 \mathrm{M}$ & Flank back, thigh & Plaques & LN, BM, PB leptomeninges & IVB & $\mathrm{D}$ (15m; after onset) \\
\hline 18 & Motegi & $62 \mathrm{M}$ & $\begin{array}{l}\text { Back,upper } \\
\text { extremities }\end{array}$ & nodules & LN,Spleen,gastric mucosa,tonsils & IVA & A (4 month,after treatment) \\
\hline
\end{tabular}

our case; when present the skin localizations are disseminated and associated with a poor prognosis. ${ }^{11,12,16}$ Although, large reactive skin lesions have not been reported previously, the absence of atypical lymphoid cells and the complete remission with chemotherapy suggest that the skin lesions should be considered in the present case as reactive to mantle cell lymphoma; however, the presence of hidden

\section{References:}

1. Burg G, Jaffe ES, Kempf W, Berti E, Cerroni L, Chimenti S, et al., WHO/EORTC. Classification of cutaneous lymphomas. In: Weedon D, LeBoit P, Burg G, Sarasin A, eds. Pathology and Genetics of Skin Tumors: WHO Classification of Tumors. Lyon: IARC, 2005: 166

2. Swerdlow SH, Kurrer M, Bernengo M, Buchner S. Cutaneous involvement in primary extracutaneous B-cell lymphoma. In: Weedon D, LeBoit P, Burg G, Sarasin A, eds. Pathology and Genetics of Tumors of the Skin: WHO Classification of Tumors. Lyon: IARC, 2005: 204-6.

3. Swerdlow SH, Nathwani BN, Berger F, Piris MA, Isaacson PI, Harris NL, et al. Mantle cell lymphoma. In: Jaffe E, Harris N, Stein H, Vardiman J, eds. Pathology and Genetics of Tumors of Haematopoietic and Lymphoid Tissue:WHO Classification of tumors. Lyon: IARC, 2001: 168-70

4. Samaha H, Dumontet C, Ketterer N, Moullet I, Thieblemont C, Bouafia F, et al. Mantle cell lymphoma: a retrospective study of malignant cells in the lesion cannot be excluded. The prognosis of MCL with skin localizations is particularly poor; aggressive chemotherapy may improve the survival rate. ${ }^{12}$ As cutaneous lesions can be the first manifestation of MCL, awareness of MCL is crucial for dermatologists and haematologists to establish an early diagnosis and perform an appropriate treatment.

121 cases. Leukemia 1998; 12: 1281-7. http://dx.doi.org/10.1038/sj.leu.2401121 PMid:9697885

5. Banks PM, Chan J, Cleary ML, Delsol G, De Wolf-Peeters C, Gatter K, et al. Mantle cell lymphoma. A proposal for unification of morphologic, immunologic, and molecular data. Am J Surg Pathol 1992; 16: 637-40. http://dx.doi.org/10.1097/00000478199207000-00001 PMid:1530105

6. Pittaluga S, Wlodarska I, Stul MS, Thomas J, Verhoef G, Cassiman JJ, et al. Mantle cell lymphoma: a clinicopathological study of 55 cases. Histopathology 1995; 26: 17-24. http://dx.doi.org/10.1111/j.1365-2559.1995.tb00615.x PMid:7713480

7. Seto M, Yamamoto K, Iida S, Akao Y, Utsumi KR, Kubonishi I, et al. Gene rearrangement and overexpression of PRAD1 in lymphoid malignancy with $\mathrm{t}(11 ; 14)(\mathrm{q} 13 ; \mathrm{q} 32)$ translocation. Oncogene 1992; 7: 1401-6. PMid:1535701

8. Yang WI, Zukerberg LR, Motokura T, Arnold A, Harris NL. 
Cyclin D1 (Bcl-1, PRAD1) protein expression in low-grade Bcell lymphomas and reactive hyperplasia. Am J Pathol 1994; 145: 86-96. PMid:7518196 PMCid: 1887308

9. Dubus P, Young P, Beylot-Barry M, Belaud-Rotureau MA, Courville P, Vergier B, et al. Value of interphase FISH for the diagnosis of $\mathrm{t}(11: 14)(\mathrm{q} 13 ; \mathrm{q} 32)$ on skin lesions of mantle cell lymphoma. Am J Clin Pathol 2002; 118: 832-41. http://dx.doi.org/10.1309/508R-YBWW-Y0AC-82GA PMid:12472275

10. Yatabe Y, Suzuki R, Tobinai K, Matsuno Y, Ichinohasama R, Okamoto M et al. Significance of cyclin D1 overexpression for the diagnosis of mantle cell lymphoma: a clinicopathologic comparison of cyclin D1-positive MCL and cyclin D1-negative MCL-like B-cell lymphoma. Blood 2000; 1: 2253-61.

11. Motegi S, Okada E, Nagai Y, Tamura A, Ishikawa O. Skin manifestation of mantle cell lymphoma. Eur J Dermatol 2006; 16 (4): 435-8 PMid 6935806

12. Canpolat F, Taş E, Albayrak Sönmez A, Oktay M, Eskioğlu F, Alper M. Cutaneous Presentation of Mantle Cell Lymphoma. Acta Derm Venereol 90, 2010;548-550 PMID: 20814647

13. Barzilai A, Shpiro D, Goldberg I, Yacob-Hirsch Y, DiazCascajo C, Meytes D, et al. Insect bite-like reaction in patients with hematologic malignant neoplasms. Arch Dermatol 1999; 135: 1503-7. http://dx.doi.org/10.1001/archderm.135.12.1503 PMid:10606056

14. Dodiuk-Gad RP, Dann EJ, Bergman R. Insect bite-like reaction associated with mantle cell lymphoma: a report of two cases and review of the literature. Int J Dermatol 2004; 43: 754-8. http://dx.doi.org/10.1111/j.1365-4632.2004.02145.x PMid: 15485536

15. Khamaysi Z, Dodiuk-Gad RP, Weltfriend S, Ben-Arieh Y, Dann EJ, Sahar D, et al. Insect bite-like reaction associated with mantle cell lymphoma: clinicopathological, immunopathological, and molecular studies. Am J Dermatopathol 2005;27:290-5.

http://dx.doi.org/10.1097/01.dad.0000164607.41402.40 PMid:16121047

16. Senff NJ, Noordijk EM, Kim YH, Bagot M, Berti E, Cerroni L, et al. European Organization for Research and Treatment of Cancer and International Society for Cutaneous Lymphomaconsensus recommendations for the management of cutaneous B-cell lymphomas. Blood 2008; 112: 1600-1609. http://dx.doi.org/10.1182/blood-2008-04-152850 PMid:18567836 